\title{
Device Reuse
}

National Cancer Institute

\section{Source}

National Cancer Institute. Device Reuse. NCI Thesaurus. Code C53613.

To use a device again. 